\title{
Toksisitas Subkronis Ekstrak Etanol Propolis Dengan Parameter Konsentrasi Glukosa, Kolesterol dan Trigliserida Pada Darah Tikus
}

\author{
Akhmad Endang Zainal Hasan*, Husnawati, Tommy Abrar \\ Departemen Biokimia, FMIPA, IPB, Jalan Agathis, Kampus IPB Darmaga, \\ Bogor,Indonesia 16888 \\ *Email Korespondensi : pakzainalhasan@gmail.com
}

Copyright (c) 2020 Universitas Pakuan

FITOFARMAKA: Jurnal Ilmiah Farmasi is licensed under a

Creative Commons Attribution-ShareAlike 4.0 International License

\begin{abstract}
ABSTRAK
Propolis merupakan salah satu bahan alam yang dimanfaatkan oleh masyarakat, antara lain sebagai antibakteri, hepatoprotektor, anestesi lokal, antikanker dan antioksidan. Penelitian ini bertujuan menentukan tingkat toksisitas subkronis ekstrak etanol 70\% propolis (EEP) pada tikus Sprague Dawley terhadap glukosa, kolesterol dan trigliserida darah selama 28 hari. Ekstrak propolis diberikan sebanyak $1 \mathrm{ml}$ secara oral pada tikus jantan dan betina sebanyak 60 ekor dan 10 ekor sebagai kontrol. Ekstrak diberikan dalam dosis $0,3 \mathrm{mg} / \mathrm{kg}$ bobot badan (BB), $2,1 \mathrm{mg} / \mathrm{kg} \mathrm{BB}, 14,7 \mathrm{mg} / \mathrm{kg} \mathrm{BB}, 102,9 \mathrm{mg} / \mathrm{kg} \mathrm{BB}$, dan $720,3 \mathrm{mg} / \mathrm{kg}$ BB sebanyak $5 \mathrm{kali}$ dalam seminggu selama 28 hari. Konsentrasi glukosa darah tikus jantan dan betina pada hari ke-28 adalah 79,85 - 97,49 mg/dL dan 61,88 - 90,26 mg/dL. Konsentrasi kolesterol darah tikus jantan dan betina pada hari ke-28 adalah 100,42 - 116,25 mg/dL dan 118,63 - 132,78 $\mathrm{mg} / \mathrm{dL}$. Konsentrasi trigliserida darah tikus jantan dan betina pada hari ke-28 adalah 128,64 $142,37 \mathrm{mg} / \mathrm{dL}$ dan $110,95-128,58 \mathrm{mg} / \mathrm{dL}$. Pemberian ekstrak etanol $70 \%$ propolis sampai dosis $720,3 \mathrm{mg} / \mathrm{kg}$ bb selama 28 hari tidak mengakibatkan abnormalitas terhadap nilai glukosa, kolesterol dan trigliserida darah tikus Sprague Dawley. Semua parameter pada hari ke-28 tidak menunjukkan perbedaan yang signifikan secara statistik dibandingkan dengan kelompok normal. Ekstrak etanol $70 \%$ propolis pada penelitian ini tidak menimbulkan pengaruh toksik pada konsentrasi glukosa, kolesterol dan trigliserida selama pengujian subkronis 28 hari. Uji ANOVA pada hari ke-28 tidak menunjukkan perbedaan nyata dibandingkan dengan kelompok normal.
\end{abstract}

Kata Kunci: Glukosa; Kolesterol; Propolis; Toksisitas subkronis, Trigliserida

\section{Subchronic Toxicity Of Propolis Ethanol Extract Using The Concentration Of Glucose, Cholesterol And Trigliceride Level In Rat Blood As A Parameters}

\section{ABSTRACT}

Propolis is one of the natural ingredients that has been used by the society, including antibacterial, hepatoprotector, local anesthetic, anticancer and antioxidant. This study aimed to determine the level of subchronic toxicity of $70 \%$ ethanol extract of propolis (EEP) in Sprague Dawley rats for blood glucose, cholesterol, and triglycerides for $28^{\text {th }}$ days. Propolis extract was given as much as $1 \mathrm{ml}$ orally in male and female mice as many as 60 rats and 10 rats as a control. Extracts were given in doses of 0,3 $\mathrm{mg} / \mathrm{kg}$ body weight, 2,1 $\mathrm{mg} / \mathrm{kg}$ body weight, 14,7 mg/kg body weight, 102,9 mg/kg body weight, and 720,3 mg/kg body weight 5 
times a week for $28^{\text {th }}$ days. Blood glucose concentrations of male and female rats on $28^{\text {th }}$ day were 79,85 - 97,49 $\mathrm{mg} / \mathrm{dL}$ and 61,88 - 90,26 $\mathrm{mg} / \mathrm{dL}$. Blood cholesterol concentrations of male and female rats on $28^{\text {th }}$ day were $100,42-116,25 \mathrm{mg} / \mathrm{dL}$ and $118,63-132,78 \mathrm{mg} / \mathrm{dL}$. Blood triglyceride concentrations of male and female rats on 28th day were 128,64 - 142,37 $\mathrm{mg} / \mathrm{dL}$ and $110,95-128,58 \mathrm{mg} / \mathrm{dL}$. The administration of $70 \%$ propolis ethanol extract up to a dose of $720.3 \mathrm{mg} / \mathrm{kg}$ bw for $28^{\text {th }}$ days did not result in abnormalities in the blood glucose, cholesterol, and triglyceride values of Sprague Dawley rats. All parameters on $28^{\text {th }}$ days did not show any statistically significant difference compared with the normal group. The ethanol extract of $70 \%$ propolis in this study did not cause a toxic effect on glucose, cholesterol, and triglyceride concentrations during the $28^{\text {th }}$ days subchronic test.The ANOVA test on $28^{\text {th }}$ days did not show a significant difference compared to the normal group.

Keywords: Cholesterol; Glucose; Propolis; Subchronic Toxicity; Triglyceride

\section{PENDAHULUAN}

Penggunaan bahan alam sebagai obat alami dipercaya secara turun temurun dan diyakini dapat mengobati berbagai penyakit. Salah satu dasar penggunaan bahan alam adalah kandungan senyawa-senyawa metabolit yang disebut senyawa fitokimia. Kecenderungan pola hidup back to nature (kembali ke alam) membuat masyarakat lebih memilih obat alami yang diyakini tidak memiliki efek samping daripada obatobat kimia, dan harganya yang lebih terjangkau daripada obat sintetik (Hernani, 2011).

Salah satu bahan alam yang sudah lama dimanfaatkan oleh masyarakat sebagai obat alami adalah propolis. Propolis adalah produk berbentuk resin yang dihasilkan oleh lebah madu untuk melindungi sarangnya. Propolis memiliki struktur padat dan lengket serta berwarna gelap. Propolis diperoleh dari getah tumbuhan yang dikumpulkan oleh lebah. Selain berperan sebagai pelindung sarang lebah bagi lebah sendiri, propolis juga bermanfaat dalam berbagai pengobatan. Banyak penelitian menunjukkan bahwa propolis berkhasiat sebagai antiinflamasi, hepatoprotektor, anestesi lokal, imunostimulator (Bankova et al., 2000), antibakteri (Artika et al., 2011; Kurniawati et al., 2011), dan antikanker (Hasan et al., 2016). Propolis memiliki berbagai khasiat tersebut karena mengandung berbagai senyawa seperti fenolik, flavonoid dan terpen (Huang et al.,
2014). Senyawa flavonoid yang terkandung di dalam propolis sangat kuat dalam perannya sebagai antioksidan (Silva et al., 2017). Aktivitas sitotoksik dan efek antiproliferasi pada propolis menunjukkan bahwa propolis memiliki potensi sebagai antikanker atau antitumor (Hadiyah et al., 2009).

Penelitian yang dilakukan oleh Hasan et al. (2016) menunjukkan bahwa ekstrak etanol $70 \%$ propolis Trigona spp. asal Indonesia memiliki aktivitas antioksidan $\left(\mathrm{IC}_{50}\right)$ sebesar $75,34 \mu \mathrm{g} / \mathrm{mL}$ dan mematikan $50 \%$ sel kanker MCF-7 pada konsentrasi $233 \mu \mathrm{g} / \mathrm{mL}$. Hasil uji kadar flavonoid dan antioksidan ekstrak etanol $70 \%$ propolis dan nano propolis juga telah dilakukan oleh Purnamasari (2016). Penelitian tersebut juga telah dilakukan uji BSLT dengan diperoleh nilai $\mathrm{LC}_{50}$ untuk ekstrak etanol $70 \%$ propolis sebesar $16,010 \mu \mathrm{g} / \mathrm{mL}$ dan nilai $\mathrm{LC}_{50}$ untuk serbuk nano propolis sebesar $18,689 \mu \mathrm{g} / \mathrm{mL}$. Penelitian yang dilakukan oleh Hasan et al. (2016) menunjukkan bahwa nano propolis asal Indonesia dosis $32 \mu \mathrm{g} / \mathrm{mL}$ dapat mengobati tumor kelenjar payudara pada tikus putih betina yang diinduksi DMBA. Hasil penelitian tersebut menunjukkan pemberian nano propolis mampu mengurangi ukuran tumor, menyembuhkan luka yang disebabkan oleh tumor dan melenyapkan tumor. Ekstrak propolis bukan nanopartikel pada konsentrasi $233 \mu \mathrm{g} / \mathrm{mL}$ juga memiliki kemampuan yang sama 
dalam mengobati tumor pada kelenjar payudara tikus putih betina.

Menurut penelitian Hasan et.al. (2016), ekstrak etanol 70\% propolis asal Indonesia diketahui memiliki senyawa antikanker payudara dan telah dilakukan penelitian terhadap tikus putih betina yang diinduksi DMBA, namun belum dilakukan uji klinis agar dapat digunakan dalam pengobatan kanker. Oleh karena itu, perlu dilakukan uji toksisitas terhadap ekstrak etanol $70 \%$ propolis asal Indonesia terlebih dahulu sebelum dilakukan uji klinis agar dapat digunakan dalam pengobatan kanker dan dijadikan sebagai obat berstandar menurut BPOM (2014), salah satunya melalui uji toksisitas subkronis. Parameter minimum yang harus diperiksa menurut BPOM (2014) adalah glukosa, kolesterol, trigliserida, nitrogen urea, kreatinin, ALT, dan AST. Hasil dari penelitian Ramdan (2018) menyebutkan bahwa pemberian ekstrak etanol $70 \%$ propolis tidak menimbulkan kelainan terhadap konsentrasi nitrogen urea dan kreatinin darah tikus Sprague Dawley. Rinaldi (2018) juga menyebutkan bahwa pemberian ekstrak etanol $70 \%$ propolis tidak menimbulkan pengaruh toksik subkronis terhadap kadar ALT dan AST hepar tikus Sprague Dawley. Penelitian ini bertujuan untuk menentukan tingkat toksisitas subkronis ekstrak etanol $70 \%$ propolis (EEP) terhadap konsentrasi glukosa, kolesterol dan trigliserida pada darah Sprague Dawley selama 28 hari.

\section{METODE PENELITIAN \\ Bahan dan Alat}

Bahan yang digunakan dalam penyiapan ekstrak propolis yaitu raw propolis sarang lebah Trigona spp asal Kendal dan etanol $70 \%$. Bahan yang digunakan dalam perlakuan dan pemeliharaan hewan coba adalah tikus jantan dan betina galur Sprague Dawley berumur 2 bulan dengan bobot badan $175 \pm 25$ gram, pakan standar BRAVO 512, air minum ad libitum, dan serbuk gergaji.
Bahan lain yang digunakan dalam pengujian kimia darah adalah serum darah tikus, kit GOD-PAP (ST-Reagensia Glucose Enzymatic Trinder), kit CHOD-PAP (Indo Reagen Cholesterol Liquid ${ }^{I R}$ Metode Warna Enzimatik), dan kit GPO-PAP (STReagensia Trigliceride GPO Enzymatic).

Alat-alat yang digunakan untuk pemeliharaan dan perlakuan hewan uji adalah kandang tikus, sonde lambung, jarum suntik, neraca analitik dan peralatan bedah, serta alat pendukung seperti kipas angin, blower dan barometer. Alat-alat yang digunakan dalam pengujian darah adalah tabung mikrosentrifus, pipet mikro, tip, microplate 96-well, dan spektrofotometer.

\section{Perlakuan Hewan Coba}

Perlakuan hewan coba dilakukan berdasarkan ketentuan dari BPOM (2014) yang meliputi aklimatisasi, persiapan hewan uji, penentuan dosis, induksi ekstrak dan monitoring berat badan dan konsumsi pakan.

\section{Aklimatisasi dan Persiapan Hewan Uji}

Tikus sebanyak 60 ekor (30 ekor jantan dan 30 ekor betina) dengan galur Sprague Dawley berumur 2 bulan sehat fisik (mata merah, bulu tidak berdiri, warna putih bersih, tingkah laku normal, dan bergerak aktif). Tikus memiliki bobot badan $175 \pm 25$ gram disiapkan. Tahap awal yang dilakukan adalah adaptasi terhadap tikus selama 14 hari. Adaptasi ini dilakukan dengan tujuan tikus dapat menyesuaikan dengan lingkungannya. Pemeliharaan tikus sesuai dengan kode etik yaitu pakan komplit butiran 512-BRAVO dan minuman ad libitum yang harus tersedia setiap waktu, serta alas tikus dari serbuk kayu yang penggantiannya disesuaikan dengan kondisi alas. Pencahayaan diperoleh secara alami melalui jendela dan pintu. Kandang dilengkapi kipas angin dan blower untuk menjaga aliran udara dan panas yang berlebih, serta dilengkapi barometer untuk memantau suhu dan kelembaban kandang. 
Hewan uji sebelum dan setelah diaklimatisasi selama 14 hari, dilakukan penimbangan bobot badan terlebih dahulu sebelum pemberian perlakukan sebagai bobot badan hari ke-0. Penimbangan bobot badan hewan uji bertujuan untuk mengetahui kehomogenan hewan uji tersebut, yang dilakukan dengan menghitung koefisien variasi. Rumus untuk menghitung koefisien variasi, sebagai berikut:

Koefisien Variasi $=\frac{\sqrt{\Sigma}\left(\mathrm{x}-\mathrm{x}_{\mathrm{i}}\right)^{2} / \mathrm{N}}{\text { Rata-rata }} \times 100 \%$

\section{Penentuan Dosis}

Dosis yang digunakan minimal ada tiga tingkatan dosis dan satu dosis satelit dengan dosis maksimum tidak lebih dari $1000 \mathrm{mg} / \mathrm{kg}$ BB dengan tingkatan masingmasing dosis ditentukan dari kelipatan dosis optimum. Penelitian ini akan digunakan dosis terendah yang sekaligus menjadi dosis optimum yaitu $0,3 \mathrm{mg} / \mathrm{kg}$ BB yang ditetapkan berdasarkan dosis terapi hasil penelitian ekstrak propolis asal Indonesia sebagai bahan antikanker payudara yang telah dilakukan oleh Hasan et al., (2016). Dosis tengah dan dosis tinggi ditetapkan dengan menggunakan faktor kelipatan 7 yaitu $2,1 \mathrm{mg} / \mathrm{kg} \mathrm{BB}, 14,7 \mathrm{mg} / \mathrm{kg} \mathrm{BB}, 102,9$ $\mathrm{mg} / \mathrm{kg} \mathrm{BB}$, dan $720,3 \mathrm{mg} / \mathrm{kg}$ BB.

\section{Induksi Ekstrak}

Sebanyak 60 ekor tikus dibagi menjadi 6 kelompok secara acak, yaitu: (1) kelompok normal, yaitu kelompok yang diberi perlakuan aquades, (2) kelompok ekstrak etanol $70 \%$ propolis dosis $0,3 \mathrm{mg} / \mathrm{kg}$ BB, (3) kelompok ekstrak etanol $70 \%$ propolis dosis $2,1 \mathrm{mg} / \mathrm{kg} \mathrm{BB}$, (4) kelompok ekstrak etanol $70 \%$ propolis dosis 14,7 $\mathrm{mg} / \mathrm{kg} \mathrm{BB}$, (5) kelompok ekstrak etanol $70 \%$ propolis dosis $102,9 \mathrm{mg} / \mathrm{kg} \mathrm{BB}$, dan (6) kelompok ekstrak etanol $70 \%$ propolis dosis 720,3 mg/kg BB. Masing-masing kandang dimasukkan sebanyak dua ekor tikus. Pemberian ekstrak dilakukan secara oral sebanyak 5 kali dalam seminggu menggunakan sonde lambung dan dilakukan pengamatan selama 28 hari.

\section{Pengambilan Serum Darah}

Darah diambil pada hari pengamatan ke-0 (sebelum perlakuan), hari pengamatan ke-7 dan hari pengamatan ke-28 (pada saat dinekropsi). Sebelum darah diambil, tikus dipuasakan selama 16 jam. Darah diambil melalui pembuluh vena pada ekor tikus sebanyak 1,5 mL. Darah kemudian ditampung ke dalam tabung mikro. Darah didiamkan selama 30 menit ruang. Selanjutnya darah disentifus dengan kecepatan 3000 rpm selama 15 menit. Supernatan diambil dan dimasukkan ke dalam tabung mikro dan disimpan dalam freezer pada suhu $4{ }^{\circ} \mathrm{C}$ hingga dilakukan uji kimia darah.

\section{Pemeriksaan Kimia Darah}

\section{Glukosa (Kit ST-Reagensia Glucose Enzymatic Trinder).}

Sebanyak $1 \mu \mathrm{L}$ serum darah direaksikan dengan $100 \mu \mathrm{L}$ pereaksi uji untuk pemeriksaan glukosa yang tersedia pada kit ke dalam sumur microplate 96, kemudian diinkubasi pada suhu $37{ }^{\circ} \mathrm{C}$ selama 5 menit. Absorbansi diukur dengan nano spektrofotometer pada panjang gelombang $505 \mathrm{~nm}$. Hal yang sama dilakukan terhadap blanko (pereaksi + akuades) dan standar (pereaksi + standar glukosa). Konsentrasi glukosa dapat dihitung dengan membandingkan absorbansi sampel dengan absorbansi glukosa standar yang dikalikan dengan konsentrasi glukosa standar. Rumus yang digunakan sebagai berikut:

Glukosa $(\mathrm{g} / \mathrm{dL})=\frac{\text { Abs. sampel }}{\text { Abs. standar }} \mathrm{x}$ konsentrasi standar $(\mathrm{g} / \mathrm{dL})$ 
Kolesterol Total (Kit Indo Reagen Cholesterol Liquid ${ }^{I R}$ )

Sebanyak $1 \mu \mathrm{L}$ serum darah direaksikan dengan $100 \mu \mathrm{L}$ pereaksi uji untuk pemeriksaan kolesterol yang tersedia pada kit ke dalam sumur microplate 96, kemudian diinkubasi pada suhu $37{ }^{\circ} \mathrm{C}$ selama 5 menit. Absorbansi diukur dengan nano spektrofotometer pada panjang gelombang $520 \mathrm{~nm}$. Hal yang sama dilakukan terhadap blanko (pereaksi + akuades) dan standar (pereaksi + standar kolesterol). Konsentrasi kolesterol dapat dihitung dengan membandingkan absorbansi sampel dengan absorbansi kolesterol standar yang dikalikan dengan konsentrasi standar. Rumus yang digunakan sebagai berikut:

Kolesterol total $(\mathrm{g} / \mathrm{dL})=\frac{\text { Abs. sampel }}{\text { Abs. standar }} \mathrm{x}$ konsentrasi standar $(\mathrm{g} / \mathrm{dL})$

Trigliserida (Kit ST-Reagensia Trygliceride GPO Enzymatic).

Sebanyak $1 \mu \mathrm{L}$ serum darah direaksikan dengan $100 \mu \mathrm{L}$ pereaksi uji untuk pemeriksaan trigliserida yang tersedia pada kit ke dalam sumur microplate 96, kemudian diinkubasi pada suhu $37{ }^{\circ} \mathrm{C}$ selama 5 menit. Absorbansi diukur dengan nano spektrofotometer pada panjang gelombang $505 \mathrm{~nm}$. Hal yang sama dilakukan terhadap blanko (pereaksi + akuades) dan standar (pereaksi + standar trigliserida). Konsentrasi trigliserida dapat dihitung dengan membandingkan absorbansi sampel dengan absorbansi trigliserida standar yang dikalikan dengan konsentrasi trigliserida standar. Rumus yang digunakan sebagai berikut:

Trigliserida $(\mathrm{g} / \mathrm{dL})=\frac{\text { Abs. sampel }}{\text { Abs. standar }} \times$ konsentrasi standar $(\mathrm{g} / \mathrm{dL})$

\section{Analisis Data}

Data hasil penelitian dianalisis mengacu pada Farida et al. (2014). Data diuji dengan metode analisis statistika one way ANOVA dengan taraf kepercayaan 5\% $(\alpha=0,05)$. Analisis ini digunakan untuk analisis kimia darah (glukosa darah, kolesterol darah, dan trigliserida darah). Selanjutnya dilakukan uji lanjutan berupa uji Duncan untuk menentukan kelompok yang berbeda nyata. Faktor yang digunakan terdiri atas satu faktor, setiap faktor memiliki 5 konsentrasi, yaitu tikus yang diberi dosis $0,3 \mathrm{mg} / \mathrm{kg} \mathrm{BB}$, tikus yang diberi dosis 2,1 $\mathrm{mg} / \mathrm{kg} \mathrm{BB}$, tikus yang diberi dosis 14,7 $\mathrm{mg} / \mathrm{kg} \mathrm{BB}$, tikus yang diberi dosis 102,9 $\mathrm{mg} / \mathrm{kg} \mathrm{BB}$, dan tikus yang diberi dosis 720,3 $\mathrm{mg} / \mathrm{kg} \mathrm{BB}$. Setiap taraf diulang sebanyak 5 kali. Model matematikanya adalah sebagai berikut:

Keterangan:

$$
\mathrm{Yij}=\mu+\alpha \mathrm{i}+\varepsilon \mathrm{ij}
$$

I $=1,2,3,4$
$\mathrm{J}=1,2,3,4$

Yij $=$ respon pengaruh konsentrasi pada taraf ke-i ulangan ke-j

$\mu \quad=$ pengaruh rata-rata umum

$\alpha \mathrm{i}=$ pengaruh konsentrasi pada taraf ke-i

eij = pengaruh acak (galat percobaan) pada konsentrasi taraf ke-i ulangan ke-j

\section{HASIL DAN PEMBAHASAN}

Hasil yang diperoleh dari Tabel 1 menunjukkan pada hari pengamatan ke-0 kelompok dosis tikus jantan memiliki konsentrasi glukosa darah pada rentang $80,64-84,77 \mathrm{mg} / \mathrm{dL}$, dengan konsentrasi glukosa darah kelompok normal sebesar 80,73 . Hasil tersebut berada pada rentang normal menurut Guyton dan Hall (2008), yaitu pada rentang 60-110 mg/dL. Pada tikus betina, kelompok dosis memiliki konsentrasi glukosa darah pada rentang 75,79 - 85,99 mg/dL dengan kelompok 
normal sebesar 81,42 mg/dL (Tabel 2). Secara keseluruhan konsentrasi glukosa darah tikus betina hari pengamatan ke-0 berada pada rentang normal. Hasil yang diperoleh menunjukkan konsentrasi glukosa darah kelompok dosis tidak berbeda nyata dengan kelompok normal pada taraf kepercayaan $5 \%$ baik tikus jantan maupun tikus betina.

Konsentrasi glukosa darah tikus jantan pada hari pengamatan ke-7 mengalami peningkatan dan berada pada rentang normal. Pada kelompok dosis 2 dan kelompok dosis 4 peningkatannya berada diatas kelompok normal menjadi 133,7 $\mathrm{mg} / \mathrm{dL}$ dan $125,68 \mathrm{mg} / \mathrm{dL}$. Pada tikus betina mengalami peningkatan pada hari ke-7 baik kelompok normal maupun kelompok dosis dan masih berada pada rentang normal. Konsentrasi glukosa darah kelompok dosis tikus betina mengalami peningkatan setiap peningkatan pemberian dosis ekstrak propolis. Hasil yang diperoleh menunjukkan konsentrasi glukosa darah kelompok dosis tidak berbeda nyata dengan kelompok normal pada taraf kepercayaan 5\% baik tikus jantan maupun tikus betina.

Pada hari pengamatan ke-28 tidak menunjukkan perbedaan secara nyata antara kelompok normal dan kelompok dosis. Konsentrasi glukosa darah tikus jantan dan betina mengalami penurunan dibandingkan dengan hari pengamatan ke-7. Penurunan yang terjadi seiring antara kelompok normal dan kelompok dosis. Usman et al. (2012) menyebutkan bahwa senyawa pterostilbene yang terkandung dalam propolis mampu menurunkan glukosa darah. Pada hari ke-7 senyawa tersebut belum berperan aktif, mungkin karena perlakuan yang dilakukan menyebabkan naiknya kadar glukosa darah. Senyawa lain yaitu quercetin dapat menghambat proses pemecahan dan absorbsi karbohidrat. Quercetin mampu menurunkan aktivitas glukokinase hepatik. Selain itu, senyawa tanin juga berperan dalam menurunkan glukosa darah. Tanin mempunyai kemampuan hipoglikemik dengan meningkatkan glikogenesis. Tanin berperan sebagai pengkelat yang dapat menghambat asupan gula dan laju peningkatan gula darah dengan mengerutkan membran epitel usus halus sehingga menghambat penyerapan sari makanan (Rahmawati dan Rifqiyati, 2014).

Penurunan konsentrasi glukosa darah pada hari ke-28 selain disebabkan oleh kandungan metabolit sekunder yang terdapat di dalam propolis, juga dapat disebabkan oleh tidak tersekresikannya hormon glukagon. Hormon ini berfungsi ketika konsentrasi glukosa darah dalam tubuh menurun, sehingga digunakan cadangan energi berupa glikogen dan lipid. Kedua cadangan energi tersebut digunakan mengembalikan konsentrasi glukosa darah hingga dalam rentang normal. Jika hormon glukagon tidak disekresikan, maka konsentrasi glukosa darah tikus yang dipuasakan akan tetap menurun, sehingga tikus tersebut dapat mengalami hipoglikemia (Nelson dan Cox, 2013).

Tabel 1. Nilai Glukosa Darah Tikus Jantan Pada H0, H7 dan H28

\begin{tabular}{lccccc}
\hline \multirow{2}{*}{$\begin{array}{l}\text { Kelompok } \\
(\mathbf{m g} / \mathbf{k g ~ B B})\end{array}$} & \multicolumn{3}{c}{ Hari pengamatan ke- $(\mathbf{m g} / \mathbf{d L})$} & \multicolumn{2}{c}{$\Delta$ Perubahan $(\%)$} \\
\cline { 2 - 6 } & $\mathrm{H} 0$ & $\mathrm{H} 7$ & $\mathrm{H} 28$ & $\mathrm{H} 0-\mathrm{H} 7$ & $\mathrm{H} 0-\mathrm{H} 28$ \\
\hline Normal & $80,73 \pm 2,7^{\mathrm{a}}$ & $102,86 \pm 27,0^{\mathrm{a}}$ & $79,85 \pm 13,2^{\mathrm{a}}$ & 22,13 & $-1,09$ \\
$\mathbf{0 , 3}$ & $80,64 \pm 5,2^{\mathrm{a}}$ & $100,38 \pm 10,9^{\mathrm{a}}$ & $93,48 \pm 17,7^{\mathrm{a}}$ & 19,74 & 12,84 \\
$\mathbf{2 , 1}$ & $81,49 \pm 7,5^{\mathrm{a}}$ & $133,69 \pm 47,2^{\mathrm{a}}$ & $92,25 \pm 15,2^{\mathrm{a}}$ & 52,20 & 10,76 \\
$\mathbf{1 4 , 7}$ & $83,28 \pm 4,1^{\mathrm{a}}$ & $107,63 \pm 8,1^{\mathrm{a}}$ & $93,39 \pm 16,1^{\mathrm{a}}$ & 24,35 & 10,11 \\
$\mathbf{1 0 2 , 9}$ & $80,85 \pm 3,5^{\mathrm{a}}$ & $125,67 \pm 40,6^{\mathrm{a}}$ & $88,85 \pm 5,6^{\mathrm{a}}$ & 44,82 & 8,01 \\
$\mathbf{7 2 0 , 3}$ & $84,77 \pm 2,4^{\mathrm{a}}$ & $117,32 \pm 12,2^{\mathrm{a}}$ & $97,49 \pm 14,1^{\mathrm{a}}$ & 32,55 & 12,72 \\
\hline
\end{tabular}


Tabel 2. Nilai Glukosa Darah Tikus Betina Pada H0, H7 dan H28

\begin{tabular}{lccccc}
\hline Kelompok & \multicolumn{3}{c}{ Hari pengamatan ke- (mg/dL) } & \multicolumn{2}{c}{$\Delta$ Perubahan (\%) } \\
\cline { 2 - 6 }$(\mathbf{m g} / \mathbf{k g ~ B B})$ & $\mathrm{H} 0$ & $\mathrm{H} 7$ & $\mathrm{H} 28$ & $\mathrm{H} 0-\mathrm{H} 7$ & $\mathrm{H} 0-\mathrm{H} 28$ \\
\hline Normal & $81,42 \pm 5,9^{\mathrm{a}}$ & $105,59 \pm 18,5^{\mathrm{a}}$ & $61,88 \pm 14,4^{\mathrm{a}}$ & 24,17 & $-19,54$ \\
$\mathbf{0 , 3}$ & $85,99 \pm 12,5^{\mathrm{a}}$ & $92,57 \pm 16,3^{\mathrm{a}}$ & $73,66 \pm 15,7^{\mathrm{a}}$ & 6,58 & $-12,33$ \\
$\mathbf{2 , 1}$ & $85,83 \pm 7,1^{\mathrm{a}}$ & $94,58 \pm 13,9^{\mathrm{a}}$ & $76,60 \pm 16,2^{\mathrm{a}}$ & 8,75 & $-9,23$ \\
$\mathbf{1 4 , 7}$ & $77,12 \pm 5,6^{\mathrm{a}}$ & $95,27 \pm 11,2^{\mathrm{a}}$ & $76,25 \pm 17,2^{\mathrm{a}}$ & 18,15 & $-0,87$ \\
$\mathbf{1 0 2 , 9}$ & $84,45 \pm 8,1^{\mathrm{a}}$ & $104,14 \pm 9,9^{\mathrm{a}}$ & $80,42 \pm 10,4^{\mathrm{a}}$ & 19,69 & $-4,03$ \\
$\mathbf{7 2 0 , 3}$ & $75,79 \pm 3,6^{\mathrm{a}}$ & $110,25 \pm 10,5^{\text {a }}$ & $90,26 \pm 16,7^{\mathrm{a}}$ & 34,52 & 14,47 \\
\hline
\end{tabular}

Keterangan: Huruf yang sama (a) pada kolom menunjukkan hasil tidak berbeda nyata secara statistika $(\alpha=0,05)$ pada uji oneway ANOVA

Berdasarkan Tabel 3 dan 4 dapat dilihat bahwa kolesterol darah tikus jantan pada hari ke-0 masih berada pada rentang normal menurut Mutia, et al., (2018), yaitu berkisar antara $40-130 \mathrm{mg} / \mathrm{dL}$, kecuali pada kelompok normal dan kelompok dosis $14,7 \mathrm{mg} / \mathrm{kg}$ BB. Pada tikus betina semua kelompok dosis dan kelompok normal memiliki nilai kolesterol darah yang berada di atas rentang normal. Pengamatan sebelum diberi perlakuan $(\mathrm{H} 0)$ menunjukkan nilai kolesterol darah tikus jantan berada pada rentang 118,28 - 138,96 mg/dL dengan kelompok normal sebesar 144,79 mg/dL. Kemudian pada tikus betina berada pada rentang 144,23 - 172,23 $\mathrm{mg} / \mathrm{dL}$, dengan kelompok normal sebesar 159,87 mg/dL. Hasil tersebut berada pada rentang normal. Secara keseluruhan nilai kolesterol darah pada H0 tidak berbeda nyata dengan kelompok normal bila dianalisis secara statistika pada taraf kepercayaan 5\%.

Konsentrasi kolesterol darah kelompok normal tikus jantan maupun tikus betina mengalami penurunan pada $\mathrm{H} 7$ dan H28. Hasil yang sama juga diperoleh dari penelitian yang telah dilakukan oleh Rumanti (2011) yang menunjukkan penurunan nilai kolesterol darah pada tikus yang diberi pakan standar. Hal tersebut disebabkan pakan standar adalah makanan rendah kolesterol. Pakan standar yang digunakan pada penelitian adalah BRAVO 512. Komposisi lemak pakan standar BRAVO 512 adalah 5-8 \%, Komposisi lemak tersebut lebih rendah dibandingkan dengan syarat pakan tinggi lemak, sehingga tidak membuat kolesterol naik tetapi justru turun (Ali et al., 2015).

Tabel 3. Nilai Kolesterol Total Darah Tikus Jantan Pada H0, H7 dan H28

\begin{tabular}{lccccc}
\hline Kelompok & \multicolumn{3}{c}{ Hari pengamatan ke- $(\mathbf{m g} / \mathbf{d L})$} & \multicolumn{2}{c}{$\Delta$ Perubahan $(\%)$} \\
\cline { 2 - 6 }$(\mathbf{m g} / \mathbf{k g ~ B B})$ & $\mathrm{H} 0$ & $\mathrm{H} 7$ & $\mathrm{H} 28$ & $\mathrm{H} 0-\mathrm{H} 7$ & $\mathrm{H} 0-\mathrm{H} 28$ \\
\hline Normal & $144,79 \pm 19,2^{\mathrm{a}}$ & $126,12 \pm 13,1^{\mathrm{a}}$ & $109,15 \pm 11,5^{\mathrm{a}}$ & $-18,67$ & $-35,64$ \\
$\mathbf{0 , 3}$ & $126,14 \pm 6,3^{\mathrm{a}}$ & $127,87 \pm 6,7^{\mathrm{a}}$ & $100,42 \pm 5,6^{\mathrm{a}}$ & 1,73 & $-25,72$ \\
$\mathbf{2 , 1}$ & $118,28 \pm 10,2^{\mathrm{a}}$ & $143,41 \pm 21,6^{\mathrm{a}}$ & $110,41 \pm 10,2^{\mathrm{a}}$ & 25,13 & $-7,87$ \\
$\mathbf{1 4 , 7}$ & $138,96 \pm 25,7^{\mathrm{a}}$ & $161,02 \pm 12,8^{\mathrm{a}}$ & $105,13 \pm 5,8^{\mathrm{a}}$ & 22,06 & $-33,83$ \\
$\mathbf{1 0 2 , 9}$ & $124,82 \pm 14,3^{\mathrm{a}}$ & $140,95 \pm 15,3^{\mathrm{a}}$ & $112,87 \pm 10,2^{\mathrm{a}}$ & 16,13 & $-11,95$ \\
$\mathbf{7 2 0 , 3}$ & $130,42 \pm 11,0^{\mathrm{a}}$ & $153,43 \pm 36,7^{\mathrm{a}}$ & $116,25 \pm 12,7^{\mathrm{a}}$ & 23,01 & $-14,17$ \\
\hline
\end{tabular}


FITOFARMAKA: Jurnal Ilmiah Farmasi, 10(2): 158-169

Tabel 4. Nilai Kolesterol Total Darah Tikus Betina Pada H0, H7 dan H28

\begin{tabular}{lccccc}
\hline Kelompok & \multicolumn{3}{c}{ Hari pengamatan ke- (mg/dL) } & \multicolumn{2}{c}{$\Delta$ Perubahan (\%) } \\
\cline { 2 - 6 }$(\mathbf{m g} / \mathbf{k g ~ B B})$ & $\mathrm{H} 0$ & $\mathrm{H} 7$ & $\mathrm{H} 28$ & $\mathrm{H} 0-\mathrm{H} 7$ & $\mathrm{H} 0-\mathrm{H} 28$ \\
\hline Normal & $159,87 \pm 6,2^{\mathrm{a}}$ & $148,15 \pm 13,6^{\mathrm{b}}$ & $132,78 \pm 3,2^{\mathrm{a}}$ & $-11,72$ & $-27,09$ \\
$\mathbf{0 , 3}$ & $172,23 \pm 18,3^{\mathrm{a}}$ & $107,99 \pm 24,3^{\mathrm{a}}$ & $119,07 \pm 9,2^{\mathrm{a}}$ & $-64,24$ & $-53,16$ \\
$\mathbf{2 , 1}$ & $164,53 \pm 19,6^{\mathrm{a}}$ & $109,61 \pm 6,8^{\mathrm{a}}$ & $123,23 \pm 16,8^{\mathrm{a}}$ & $-54,92$ & $-41,3$ \\
$\mathbf{1 4 , 7}$ & $144,23 \pm 30,2^{\mathrm{a}}$ & $103,92 \pm 15,7^{\mathrm{a}}$ & $118,63 \pm 26,6^{\mathrm{a}}$ & $-40,31$ & $-25,49$ \\
$\mathbf{1 0 2 , 9}$ & $155,11 \pm 6,6^{\mathrm{a}}$ & $125,33 \pm 22,3^{\mathrm{a}}$ & $131,65 \pm 18,8^{\mathrm{a}}$ & $-29,78$ & $-23,46$ \\
$\mathbf{7 2 0 , 3}$ & $148,04 \pm 9,0^{\mathrm{a}}$ & $154,61 \pm 11,6^{\mathrm{b}}$ & $122,64 \pm 33,3^{\mathrm{a}}$ & 6,57 & $-25,4$ \\
\hline
\end{tabular}

Keterangan: Huruf yang sama (a) pada kolom menunjukkan hasil tidak berbeda nyata secara statistika $(\alpha=0,05)$ pada uji one way ANOVA

Penurunan yang terjadi pada hari ke28 dipengaruhi oleh senyawa aktif yang terkandung di dalam propolis. Menurut Wardani et al. (2016) senyawa antioksidan yang terkandung dalam propolis, yaitu flavonoid, vitamin B komplek dan beta karoten dapat menurunkan kadar kolesterol total. Senyawa antioksidan dapat mencegah terjadinya stres oksidatif sehingga menghambat peningkatan nilai kolesterol, Propolis dapat menghambat pembentukan anion superoksida yang diproduksi selama autooksidasi $\beta$-merkaptoetanol (Castaldo dan Capasso, 2002). Salah satu senyawa yang terkandung di dalam propolis sebagai senyawa antioksidan paling kuat adalah caffeic acid phenethyl ester (CAPE). Selain itu, Albokhadaim (2015) menyebutkan bahwa propolis dapat menghambat biosintesis kolesterol, yaitu dengan menghambat HMG-CoA reductase. Penelitian yang dilakukan oleh Koya-Miyata et al. (2009) juga menunjukkan bahwa pemberian ekstrak propolis dapat menurunkan ekspresi 3-hidroksi-3metilglutaril-koenzim A sintase 1 (HMGCS1) dan squalena epoksidase (SQLE).

Berdasarkan Tabel 5 dan 6 dapat dilihat bahwa pada awal pemberian propolis selama 7 hari konsentrasi trigliserida pada tikus jantan mengalami penurunan pada semua kelompok normal dan kelompok dosis, sedangkan pada H-28 hanya pada kelompok dosis 2, 3, dan 5 yang mengalami penurunan konsentrasi trigliserida. Pada tikus betina terjadi peningkatan pada $\mathrm{H} 7$, kecuali pada kelompok normal dan dosis 4 , kemudian pada H28 semua kelompok normal dan kelompok dosis mengalami penurunan. Perubahan yang terjadi tidak signifikan apabila dibandingkan dengan kelompok normal yang dianalisis secara statistik tidak menunjukkan perbedaan nilai nyata. Menurut Suckow et al, (2006), nilai normal trigliserida darah tikus berkisar antara 25 - $145 \mathrm{mg} / \mathrm{dL}$. Konsentrasi trigliserida darah tikus jantan berada dalam rentang normal pada H0 (130,89 - 141,09 $\mathrm{mg} / \mathrm{dL}), \mathrm{H} 7$ (118,93 - 137,96 mg/dL), dan H28 (128,64 - 142,37 mg/dL), namun nilai trigliserida darah tikus betina berada dalam rentang normal kecuali pada $\mathrm{H} 7$ pada dosis $1(156,33 \mathrm{mg} / \mathrm{dL})$, dosis $3(168,40 \mathrm{mg} / \mathrm{dL})$, dan dosis 5 (150,92 mg/dL).

Pada hari pengamatan ke-28 tidak menunjukkan perbedaan secara nyata antara kelompok normal dan kelompok dosis. Hasil akhir pengamatan menunjukkan penurunan nilai kolesterol darah total pada semua kelompok dosis tikus jantan dan tikus betina dibandingkan dengan $\mathrm{H} 0$. Hasil tersebut menunjukkan bahwa propolis mempunyai efek dalam memperbaiki profil lipid yaitu dapat menurunkan kolesterol total dan trigliserida serta dapat meningkatkan kolesterol HDL. Propolis mengandung vitamin $\mathrm{C}$, vitamin $\mathrm{E}$, steroid dan flavonoid sebagai antioksidan yang dapat melindungi sel lemak dari proses oksidasi (El-Sayed et al., 2009). 
Tabel 5. Nilai Trigliserida Darah Tikus Jantan Pada H0, H7 dan H28

\begin{tabular}{lccccc}
\hline Kelompok & \multicolumn{3}{c}{ Hari pengamatan ke- $(\mathbf{m g} / \mathbf{d L})$} & \multicolumn{2}{c}{$\Delta$ Perubahan $(\%)$} \\
\cline { 2 - 6 }$(\mathbf{m g} / \mathbf{k g}$ BB $)$ & $\mathrm{H} 0$ & $\mathrm{H} 7$ & $\mathrm{H} 28$ & $\mathrm{H} 0-\mathrm{H} 7$ & $\mathrm{H} 0-\mathrm{H} 28$ \\
\hline Normal & $130,89 \pm 6,7^{\mathrm{a}}$ & $118,93 \pm 8,8^{\mathrm{a}}$ & $134,09 \pm 11,3^{\mathrm{a}}$ & $-11,96$ & 3,2 \\
$\mathbf{0 , 3}$ & $138,34 \pm 5,7^{\mathrm{a}}$ & $127,48 \pm 10,6^{\mathrm{a}}$ & $142,37 \pm 9,9^{\mathrm{a}}$ & $-10,86$ & 4,03 \\
$\mathbf{2 , 1}$ & $140,03 \pm 17,6^{\mathrm{a}}$ & $128,46 \pm 22,9^{\mathrm{a}}$ & $128,64 \pm 11,5^{\mathrm{a}}$ & $-11,57$ & $-11,39$ \\
$\mathbf{1 4 , 7}$ & $140,55 \pm 19,8^{\mathrm{a}}$ & $122,20 \pm 14,0^{\mathrm{a}}$ & $136,40 \pm 19,8^{\mathrm{a}}$ & $-18,35$ & $-4,15$ \\
$\mathbf{1 0 2 , 9}$ & $136,15 \pm 1,3^{\mathrm{a}}$ & $129,13 \pm 20,5^{\mathrm{a}}$ & $136,25 \pm 10,9^{\mathrm{a}}$ & $-7,02$ & 0,1 \\
$\mathbf{7 2 0 , 3}$ & $141,09 \pm 10,2^{\mathrm{a}}$ & $137,96 \pm 8,9^{\mathrm{a}}$ & $135,40 \pm 14,1^{\mathrm{a}}$ & $-3,13$ & $-5,69$ \\
\hline
\end{tabular}

Kombinasi kandungan vitamin $\mathrm{C}$ dan vitamin $\mathrm{E}$ terjadi efek sinergis antioksidan sehingga menjadi sangat efektif. Vitamin E dapat melindungi membran lipid dari proses oksidasi. Vitamin E efektif menghentikan reaksi radikal bebas. Radikal vitamin $\mathrm{E}$ dapat berinteraksi secara langsung dengan radikal peroksida lemak sehingga kehilangan atom hidrogen lain, sehingga menghambat peroksidasi lemak dengan memberikan elektron tunggal untuk membentuk tokoferil kuinon yang stabil (Rumanasari 2006; Krisnansari et al., 2012). Selain itu, flavonoid yang terkandung dalam propolis dapat memperlancar sirkulasi darah dan sirkulasi senyawa metabolit di dalam darah sehingga menstimulasi penggunaan trigliserida dari darah untuk menghasilkan energi. Propolis juga mampu mengatur metabolisme lipid dan mengurangi sindrom yang disebabkan oleh kelainan lipid darah (Fuliang et al., 2005; Klaric et al., 2018).
Selain itu, penurunan konsentrasi trigliserida darah juga dapat disebabkan oleh proses pemuasaan tikus untuk pengambilan darah yang terlalu lama. Hal tersebut menyebabkan terjadi perombakan trigliserida, Oleh karena itu, terjadi penurunan konsentrasi trigliserida darah. Terjadinya penurunan kadar senyawa tersebut diakibatkan adanya flavonoid dan pterostilbene dalam propolis. Tetapi penurunan terjadi sampai batas normal dan tidak menjadikan hipoglikemia.

Pada penelitian ini hanya meninjau konsentrasi glukosa, kolesterol dan trigliserida tidak untuk konsentrasi yang lain dalam kaitan parameter subkronis selama 28 hari pengamatan. Oleh karena itu untuk melihat secara lengkap tinjauan subkronis suatu bahan perlu dilakukan terhadap parameter lainnya sehingga lengkap dan komprehensif.

Tabel 6. Nilai Trigliserida Darah Tikus Betina Pada H0, H7 dan H28

\begin{tabular}{lccccc}
\hline \multirow{2}{*}{$\begin{array}{l}\text { Kelompok } \\
(\mathbf{m g} / \mathbf{k g ~ B B})\end{array}$} & \multicolumn{3}{c}{ Hari pengamatan ke- $(\mathbf{m g} / \mathbf{d L})$} & \multicolumn{2}{c}{$\Delta$ Perubahan $(\%)$} \\
\cline { 2 - 6 } Normal & $137,27 \pm 15,2^{\mathrm{a}}$ & $130,63 \pm 10,2^{\mathrm{a}}$ & $113,96 \pm 5,7^{\mathrm{a}}$ & $-6,64$ & $-23,31$ \\
$\mathbf{0 , 3}$ & $142,01 \pm 11,5^{\mathrm{a}}$ & $156,33 \pm 27,4^{\mathrm{a}}$ & $128,58 \pm 6,2^{\mathrm{b}}$ & 14,32 & $-13,43$ \\
$\mathbf{2 , 1}$ & $138,11 \pm 19,6^{\mathrm{a}}$ & $144,93 \pm 17,7^{\mathrm{a}}$ & $122,10 \pm 13,1^{\mathrm{a}}$ & 6,82 & $-16,01$ \\
$\mathbf{1 4 , 7}$ & $127,56 \pm 13,5^{\mathrm{a}}$ & $168,40 \pm 40,7^{\mathrm{a}}$ & $116,68 \pm 10,7^{\mathrm{a}}$ & 40,84 & $-10,88$ \\
$\mathbf{1 0 2 , 9}$ & $133,98 \pm 12,1^{\mathrm{a}}$ & $126,99 \pm 12,7^{\mathrm{a}}$ & $128,40 \pm 15,5^{\mathrm{a}}$ & $-6,99$ & $-5,58$ \\
$\mathbf{7 2 0 , 3}$ & $138,04 \pm 11,9^{\mathrm{a}}$ & $150,92 \pm 17,2^{\mathrm{a}}$ & $110,95 \pm 8,4^{\mathrm{a}}$ & 12,88 & $-27,09$ \\
\hline Keterangan: Huruf yang sama (a) pada kolom menunjukkan hasil tidak berbeda nyata secara statistika \\
$(\alpha=0,05)$ pada uji one way ANOVA
\end{tabular}




\section{KESIMPULAN}

Pemberian ekstrak etanol $70 \%$ propolis sampai dosis $720,3 \mathrm{mg} / \mathrm{kg}$ bb selama 28 hari tidak mengakibatkan abnormalitas terhadap nilai glukosa, kolesterol dan trigliserida darah tikus Sprague Dawley. Semua parameter pada hari ke-28 tidak menunjukkan perbedaan yang signifikan secara statistik dibandingkan dengan kelompok normal. Ekstrak etanol $70 \%$ propolis pada penelitian ini tidak menimbulkan pengaruh toksik pada konsentrasi glukosa, kolesterol dan trigliserida selama pengujian subkronis 28 hari.

\section{UCAPAN TERIMA KASIH}

Terima kasih penulis ucapkan kepada Ketua Departemen Biokimia FMIPA IPB dan kepada Dekan FMIPA IPB yang telah mengizinkan penulis melakukan penelitian. Ucapan terima kasih juga disampaikan kepada Rektor IPB yang telah memberikan dana penelitian lewat skema Penelitian Unggulan Perguruan Tinggi. Ucapan terima kasih disampaikan juga kepada peneliti lain yang telah bekerjasama dalam menyelesaikan penelitian payung ini.

\section{DAFTAR PUSTAKA}

Badan Pengawas Obat dan Makanan. (2014). Pedoman uji toksisitas nonklinik secara in vivo.. http://www/google/BPOM. Diunduh pada 15 Januari 2018.

Adelina, R., Supriyati, M.D., Nawangsari, D.A., Jenie R.I. \& Meiyanto, E. 2008. Citrus reticulata's peels modulate blood cholesterol profile and increase bone density of ovariectomized rats. Indonesian Journal of Biotechnology, 15(2): 1092-1097.

Albokhadaim, I. (2015). Influence of dietary supplementation of propolis on hematology, biochemistry and lipid profile of rats fed high cholesterol diet. Journal of Advanced Veterinary and Animal Research, 2(1): 56-63.

Ali, A., Amalia L. \& Suptijah, P. (2015). Pemberian kitosan dan pengaruhnya terhadap berat badan dan kadar trigliserida darah tikus Sprague Dawley yang diberi pakan asam lemak trans. Jurnal Gizi Pangan, 10(1): 9-16.

Artika, I.M., Susilo, H., Setyo, A.V.D. \& Hasan, A.E.Z. (2011). Antibacterial activity of propolis supplementedchewing candy against Streptococcus mutans. Microbiology, 5(3): 99-102.

Bankova, V., Castro, S.L. \& Marcucci, M.C. (2000). Propolis: recent advances in chemistry and plant origin. Apidol, 31(1): 3-15.

Castaldo, S. \& Capasso, F. (2002). Propolis, an old remedy used in modern medicine. Fitoterapia, 73(1): 1-6.

El-Sayed, S.M., Abo-Salem, O.M., Aly, H.A. \& Mansour, A.M. (2009). Potential antidiabetic and hypolipidemic effects of propolis extract in streptozotocin-induced diabetic rats. Pakistan Journal of Pharmaceutical Sciences, 22(2): 168174.

Farida, V., Ikawati, Z. \& Pramono, S. (2014). Uji toksisitas subkronis ekstrak curcuma bebas minyak atsiri (ECBA) ditinjau dari parameter profil leukosit pada tikus putih galur wistar. Pharmaciana, 4(1): 53-58.

Fuliang, H.U., Hepburn, H.R., Xuan, H., Chen, M., Daya, S. \& Radloff, S.E. (2005). Effect of propolis on blood glucose, blood lipid and free radicals in rats with diabetes mellitus. Pharmacology Research, 51(2): 147152.

Guyton, A.C. \& Hall, J.E. (2008). Buku Ajar Fisiologi Kedokteran Ed ke-11. (Textbook of Medical Physiology, penerjemah Irawati et al.,). 
Penerbit Buku Kedokteran EGC. Jakarta.

Hadiyah, Z.K., Widyarti, S. \& Widodo, M.A. (2009). Ekstrak propolis lokal mempunyai efek sitotoksik dan antiproliferatif terhadap sel hela. Jurnal Kedokteran Brawijaya, XXV (1). 17-22.

Hasan, A.E.Z., Mangunwidjaja, D., Sunarti, T.C., Suparno, O. \& Setiyono, A. (2016). Anti Breast cancer activity of nano propolis Indonesia on induced mammary gland tumor by DMBA in virgin Sprague Dawley. Biotropia, 23(1): 35-41.

Hernani. (2011). Pengembangan biofarmaka sebagai obat herbal untuk kesehatan. Buletin Teknologi Pascapanen Pertanian, 7(1): 20-29.

Huang, S., Zhang, C.P., Wang, K., Li, G.Q. \& Hu, F.L. (2014). Recent advances in the chemical composition of propolis. Molecules, 19: 1961019632.

Klaric, I., Miskulin, I., Seric, V., Dumic, A., Jonjic, J. \& Miskulin, M. (2018). The effect of propolis and bee pollen supplementation on biochemical blood parameters of broilers. Acta Veterinaria Beograd, 68(2): 190-200.

Krisnansari, D., Hapsari, A.T., Sulistyoningrum, E. \& Prastowo, A. (2012). Pengaruh propolis terhadap profil lipid tikus model hiperkolesterolemia. Jurnal Gizi Klinik Indonesia, 8(3): 106-112.

Koya-Miyata, S., Arai, N., Mizote, A., Taniguchi, Y. \& Ushio, S. (2009). Propolis prevents diet-induced hyperlipidemia and mitigates weight gain in diet-induced obesity in mice. Biological \& Pharmaceutical Bulletin, 32(12): 2022-2028.

Mutia, S., Fauziah \& Thomy, Z. (2018). Pengaruh pemberian ekstrak etanol daun andong (Cordyline fruticosa (L.) A. Chev) terhadap kadar kolesterol total dan trigliserida darah tikus putih
(Rattus

norvegicus)

hiperkolesterolemia.

Bioleuser, 2(2):29-35.

Nelson, D.L. \& Cox, M.M. (2013). Lehninger Principles of Biochemistry Sixth Edition. W. H. Freeman and Company. New York.

Paulina, A.J., Asni, E. \& Gaffar, M. (2015). Pengaruh lama pemberian diet aterogenik terhadap indeks aterogenik serum Rattus norvegicus strain wistar jantan. Jurnal Online Mahasiswa Bidang Kedokteran, 2(2): 1-15.

Purnamasari, A. (2016). Uji toksisitas, aktivitas antioksidan dan penentuan kadar flavonoid total ekstraksi etanol $70 \%$ propolis serta serbuk propolis [skripsi]. Bogor(ID): Universitas Pakuan.

Rahmawati, S. \& Rifqiyati, N. 2014. Efektivitas ekstrak kulit batang, akar, dan daun sirsak (Annona muricata L) terhadap kadar glukosa darah. Jurnal Kaunia. 10(2): 81-91.

Ramdan, I. 2018. Uji toksisitas subkronis ekstrak etanol $70 \%$ propolis terhadap kadar nitrogen urea dan kreatinin serum darah tikus Sprague Dawley [skripsi]. Bogor (ID): Universitas Pakuan.

Rinaldi, I. (2018). Uji toksisitas subkronis ekstrak etanol propolis Trigona spp. asal Kendal terhadap kadar sgot dan sgpt hepar tikus Sprague Dawley. Skripsi. Universitas Pakuan.

Rumanasari, E. A., Hadi, H. \& Achadiono, I.N.W. (2006). Pengaruh suplementasi vitamin $\mathrm{C}$ dan vitamin $\mathrm{E}$ terhadap profil lipid pada pasien penyakit jantung koroner di poliklinik kardiologi RSUD Dr. Slamet Garut. Sains Kesehatan, 19(2). 183-195.

Rumanti, R.T. (2011). Efek propolis terhadap kadar kolesterol total pada tikus model tinggi lemak. Maranatha Journal of Medicine and Health, 11(1): 17-22. 
Silva, R.P.D., Machado, B.A.S., Barrelo, G.A., Costa, S.S., Andrade, L.N., Amaral, R.G., Carvalho, A.A., Padilha, F.F., Barbosa, J.D.V. \& Guez, M.A.U. (2017). Antioxidant, antimicrobial, antiparasitic, and cytotoxic properties of various Brazilian propolis extracts. PLoS ONE, 12(3): 1-18.

Suckow, M.A., Weisbroth, S.H. \& Franklin, C.L. (2006). The Laboratory Rat. Elsevier Academic Press. San Diego.
Usman, A.N., Abdullah, A.Z., Hakim, B.A. \& Asir, A.A. (2012). Pengaruh pemberian propolis terhadap gangguan glukosa darah puasa dan gangguan toleransi glukosa penderita prediabetes. J Masy Epid, 1(2): 84-91. Wardani, C.S., Budirahardjo, R. \& Yuwono, B. (2016). Pengaruh pemberian ekstrak propolis terhadap kadar kolesterol darah tikus wistar jantan setelah dipapar sidestream cigarette smoke. e- J Pustaka Kesehatan, 40(3): 540-546. 